\title{
Great Lakes Basin Snow-Cover Ablation and Synoptic-Scale Circulation $\mathscr{O}$
}

\author{
ZACHARY J. SURIANO a AND DANIEL J. LEATHERS \\ Department of Geography, University of Delaware, Newark, Delaware
}

(Manuscript received 17 October 2017, in final form 7 May 2018)

\begin{abstract}
Synoptic-scale atmospheric conditions play a critical role in determining the frequency and intensity of snow-cover-ablation events. Using a synoptic weather-classification technique, distinct regional circulation patterns influencing the Great Lakes basin of North America are identified and examined in conjunction with daily snow-ablation events from 1960 to 2009. An ablation event is considered in this study to be an interdiurnal decrease in areal-weighted average snow depth of greater than $2.54 \mathrm{~cm}$ in magnitude over the entire Great Lakes basin. General meteorological characteristics associated with ablation-causing synoptic types are examined, and three individual case studies from prominent synoptic types are presented to understand the diversity of meteorological influences on regional snow ablation. Results indicate that a variety of synoptic weather conditions lead to snow ablation in the Great Lakes basin. The 10 most common synoptic types accounted for $66 \%$ of the 349 ablation events detected from 1960 to 2009. Snow ablation in the Great Lakes basin most commonly occurs when there is advection of warm and moist air into the region to provide the sensible and latent heat fluxes that are needed for melt, but ablation frequently occurs during rain-on-snow events and in instances of high pressure overhead. Ablation magnitude is highest during rain-on-snow synoptic types, and the interannual frequency of these types significantly decreased by 37\% over 1960-2009. Conversely, the frequency of high-pressure-overhead synoptic types significantly increased by more than $30 \%$ from 1960 to 2009. Such changes may influence the hydrologic impact of these synoptic types on ablation over time.
\end{abstract}

\section{Introduction}

Snow-cover ablation plays a key role in the hydrologic cycle in many regions across the globe, contributing to soil moisture availability, streamflow, and groundwater supplies (Barnett et al. 2005). The lack of consistency in the volume and/or timing of snowmelt events associated with ephemeral snow cover can, however, lead to harmful societal and environmental consequences. The variable release of water from the snowpack may result in snowmelt-induced flooding, pollutant or excess nutrient transport, and water stress along snowmelt-fed rivers. During 1972-2006, 48 major snowmelt floods

Supplemental information related to this paper is available at the Journals Online website: https://doi.org/10.1175/JAMC-D-170297.s1.

\footnotetext{
${ }^{\text {a }}$ Current affiliation: Department of Geography and Geology, University of Nebraska at Omaha, Omaha, Nebraska.
}

Corresponding author: Zachary J. Suriano, zsuriano@udel.edu occurred in the United States, resulting in an average of \$69 million in losses per event (Changnon 2008).

In the Great Lakes basin of North America, annual runoff is dominated by snowmelt (Barnett et al. 2005), and snowmelt is considered the primary driver behind the seasonal cycle of the Great Lakes' water levels in spring and summer (Quinn 2002). A number of negative ecological and environmental consequences are linked to variable lake levels including those impacting wildlife habitats (Fracz and Chow-Fraser 2013). Changes to snow-ablation events within the basin therefore could substantially alter the timing of runoff, influencing soil moisture availability, lake levels, and ecological environments.

Snow-ablation-event variability is in part a function of the synoptic-scale atmospheric conditions that influence the heat and moisture transfers over a region (Grundstein and Leathers 1999). As such, synoptic classification techniques can be employed to assist in the evaluation of the atmosphere's influence on the snowpack. These techniques represent days with similar atmospheric conditions as a single synoptic weather type 
(Yarnal 1993), where each type influences the region and snowpack in a unique manner. Synoptic classification techniques have been utilized in a number of studies examining ablation in midlatitude regions globally (Grundstein and Leathers 1999; Leathers et al. 2004; Bednorz 2009; Bednorz and Wibig 2015). In many cases, snow ablation is favored during synoptic types that advect warm and moist air into a region and/or result in rain-on-snow precipitation.

To determine the synoptic-scale weather conditions that result in snow-ablation events in the Great Lakes basin, this study utilizes an eigenvector-based synoptic weather typing classification technique similar to that of Kalkstein and Corrigan (1986) to create a daily synoptic calendar from 1960 to 2009. Snow-ablation events exceeding $2.54 \mathrm{~cm} \mathrm{day}^{-1}$ averaged over the entire basin are identified, and the associated synoptic-scale weather patterns are analyzed. By using a synoptic classification approach, insights are gained into how each synoptic type modifies the snowpack individually and the frequency of each type can be tracked over time. Detailed case studies from three of the most prominent synoptic types are presented to highlight the interactions between snow ablation, surface energy fluxes, and synoptic-scale atmospheric circulation.

\section{Method and datasets}

\section{a. Temporal synoptic index}

Daily synoptic weather types are developed from 1960 to 2009 using a procedure similar to the temporal synoptic index (TSI; Kalkstein and Corrigan 1986). The procedure classifies synoptic-scale weather types by relying on a principal component analysis (PCA) and subsequent cluster analysis of meteorological observations (e.g., Suriano and Leathers 2017b), and has been successfully utilized for a variety of meteorological applications (Ellis and Leathers 1996; Suriano and Leathers 2017c; among others).

Meteorological observations of temperature, dewpoint, atmospheric pressure, $u$ - and $v$-component winds, and cloud cover are obtained four times daily (0900, 1500, 2100, and 0300 UTC) from Flint, Michigan [Weather Bureau Army Navy (WBAN) station 14826; $42.97^{\circ} \mathrm{N}, 83.75^{\circ} \mathrm{W}$ ], from 1960 to 2009 . The Flint station is chosen on the basis of its relatively centralized location within the Great Lakes basin and its sufficiently long and complete period of record. An unrotated $\mathrm{R}$-mode PCA is conducted on the data to reduce the original 24 variables (6 variables at four times per day) for each day into a set of linearly independent components. The PCA is conducted for the four climatological seasons individually [September-November (SON), December-February (DJF), March-May (MAM), and June-August (JJA)], as opposed to a single annual analysis. Seasonal classifications limit the influence of the annual cycle on the synoptic patterns, because conducting the PCA over the entire year would result in much of the explained variance representing the annual cycle and not the unique features of the individual synoptic types (Suriano and Leathers 2017b,c). With no ablation events occurring during the summer (JJA), these months are excluded from analysis.

For each climatological season, principal components with eigenvalues greater than 1.0 are retained based on the scree plot, and their resulting component scores are analyzed. For more detail on PCA and eigenvalues, see Wilks (2011). Component scores indicate the importance of a given principal component to that day's meteorological conditions, and are based on the magnitude of the original variables and the contribution of each component to their variance (Kalkstein and Corrigan 1986). With days with similar meteorological characteristics having similar component scores, cluster analysis techniques can categorize those days into distinct groups. Within-groups average-linkage cluster analysis is found to be the most appropriate clustering technique for the TSI method (Kalkstein et al. 1987) and is conducted on the resulting seasonal PCA output using an initial 20-cluster solution. Twenty clusters represents a typical maximum number of solutions and prevents synoptic weather types from being coerced because of constraints on the number of initial solutions (e.g., Suriano and Leathers 2017b). The final result of the procedure is a daily synoptic calendar from 1960 to 2009, on which each day is classified as a particular synoptic weather type that can be analyzed in conjunction with daily snow-cover-ablation events.

\section{b. Snow dataset and Great Lakes basin definition}

Snow data come from a quality-controlled, daily North American dataset of snowfall, snow depth, temperature, and precipitation interpolated onto a $1^{\circ}$ grid, archived at Rutgers, the State University of New Jersey (http://climate.rutgers.edu/snowcover/noaamelt/; Dyer and Mote 2006; Kluver et al. 2016). Data are interpolated from observation stations within the U.S. Cooperative Observer Program (COOP) and the Meteorological Service of Canada. The extensive quality control conducted on the data is outlined in Robinson (1988) and Suriano and Leathers (2017a).

For this study, the Great Lakes basin is defined at a $1^{\circ}$ resolution and is based on the gridcell centroids of the snow dataset being contained within the basin's geographical boundary. The boundary is defined by the 
hydrological units from the U.S. Geological Survey's "Watershed Boundary Dataset" (http://nhd.usgs.gov/ wbd.html), and the "Drainage Areas Dataset" by Natural Resources Canada (http://geogratis.gc.ca/). A single grid cell $\left(42.5^{\circ} \mathrm{N}, 77.5^{\circ} \mathrm{W}\right)$ was added to this definition as the vast majority of the grid cell fell within the basin, with the exception of the relatively narrow band that included the grid cell's centroid, rendering the centroid method inappropriate. Collectively, 57 one-degree grid cells constitute the Great Lakes basin in this study.

\section{c. Ablation definition}

Because snow data from the cooperative network contain no information on water equivalent, changes in daily snow depth have been defined as ablation in prior work (Grundstein and Leathers 1998; Leathers et al. 2004; Dyer and Mote 2007; Suriano and Leathers 2017a). In this study, an ablation event is considered to be an interdiurnal decrease in basinwide average snow depth exceeding $2.54 \mathrm{~cm}$. Further criteria defining an ablation event include using only those instances in which the maximum daily temperature on the second day of the associated ablation event is above $0^{\circ} \mathrm{C}$ (Dyer and Mote 2007; Suriano and Leathers 2017a) and excluding days on which greater than $2.54 \mathrm{~cm}$ of new snow accumulations were recorded on any of the previous three days preceding the event. Daily snow depth for the Great Lakes basin is determined by calculating a daily areal-weighted average depth from the 57 grid cells contained within the basin. The $2.54-\mathrm{cm}$ ablation threshold is selected because it represents the first physically measureable quantity of snow-depth change from the measurement practices of the COOP network in the United States.

Although the Great Lakes basin covers a relatively large geographic area and snow depths can be spatially variable, average seasonal snow cover very often covers the entire basin, permitting analysis for the basin on the whole. An ablation event of at least $2.54 \mathrm{~cm}$ can only occur if the average basinwide snow depth is at least that depth. Furthermore, using a $2.54-\mathrm{cm}$ threshold for a basinwide ablation event does not mean this much snow is ablated equally across all portions of the basin; an ablation event for a given day may be spatially inhomogeneous depending on the current snow depth and meteorological conditions. This is specifically the case for events that cause melt in the southern and eastern portions of the basin while snow accumulates in the western and northern portions, potentially resulting in a dampened ablation signal across the entire basin. Despite this, valuable information about the atmospheric controls on snow ablation dynamics for the basin on the whole can be gathered.
It is important to note that, beyond snowmelt, decreases in snow depth may also occur as a result of physical factors such as sublimation and compaction of the snowpack and/or because of nonphysical factors related to the measurement process. Sublimation can considerably reduce the mass of a snowpack over large spatial scales in regions with a high occurrence of dry air masses. This effect, however, is minimal for a single storm (Déry and Yau 2002) and air masses over the Great Lakes region generally contain relatively high water vapor content. Similarly, compaction of the snowpack due to destructive metamorphism of snow crystals can substantially decrease the depth of the snowpack without modifying its mass (Colbeck 1983). By utilizing the temperature requirement in defining ablation events, the effect of snowpack compaction is removed as effectively as possible. Under conditions in which the temperature exceeds $0^{\circ} \mathrm{C}$ and a large snow accumulation event does not occur during the previous three days, the portion of the depth change attributable to compaction is minimized as the snowpack can be assumed to be relatively mature and isothermal (Dyer and Mote 2007). Three days was chosen on the basis of an estimated snow-density calculation (Anderson 1976) that showed that after this period the impact of compaction should be nominal at the given $2.54-\mathrm{cm}$ threshold. The impact of depth changes due to errors or biases in the measurement processes should be minimized by the quality-control measures taken to flag and remove snow-depth changes that are inconsistent with the meteorological conditions (Suriano and Leathers 2017a).

\section{Results}

An ablation event for the Great Lakes basin is defined as an interdiurnal decrease of areal-weighted basinwide average snow depth in excess of $2.54 \mathrm{~cm}$. In the Great Lakes basin, 7.0 events occur per year (std $\operatorname{dev} \sigma=3.6$ ) on average, with a range of 2-19 events per year. When an event occurs, an average of $3.8 \mathrm{~cm}$ of snow ablates across the entire Great Lakes basin $(\sigma=$ 1.2). The seasonal cycle of ablation indicates that events predominantly occur between the months of December and April; however, on average, only two months have more than one ablation event per year: February (1.3 events per year) and March (3.3 events per year; see the figure in the online supplementary material). The ablation magnitude per event is relatively consistent during the melt season. No statistically significant trends in ablation frequency or magnitude are detected from 1960 to 2009. 

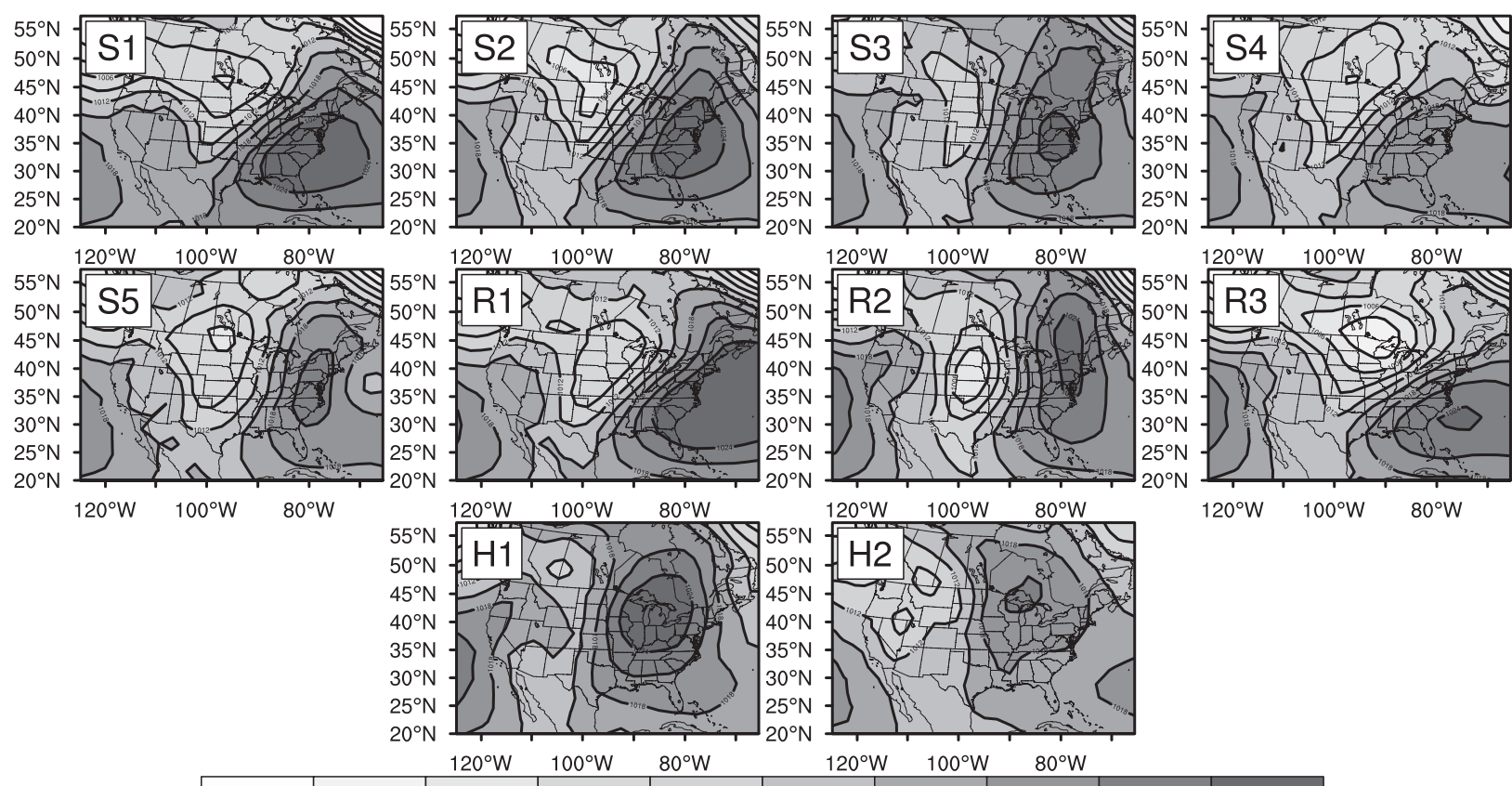

$120^{\circ} \mathrm{W} \quad 100^{\circ} \mathrm{W} \quad 80^{\circ} \mathrm{W}$

$120^{\circ} \mathrm{W} \quad 100^{\circ} \mathrm{W} \quad 80^{\circ} \mathrm{W}$

$\begin{array}{lllllllll}1000 & 1003 & 1006 & 1009 & 1012 & 1015 & 1018 & 1021 & 1024\end{array}$

FIG. 1. Composite fields of sea level pressure (hPa) for the 10 most common synoptic weather types leading to ablation. Results are grouped by category: southerly flow (S1-S5), rain on snow (R1-R3), and high overhead (H1 and H2).

\section{a. Synoptic analysis}

The PCA of the TSI procedure yields five principal components with eigenvalues greater than 1.0 for each of the climatological seasons. In autumn (SON), winter (DJF), and spring (MAM), the five components respectively explain $80.5 \%, 79.3 \%$, and $77.7 \%$ of their seasonal variance. During the spring (MAM), principal component 1 explains over $33 \%$ of the variance, with the highest loadings on air temperature and dewpoint. Principal component 2 has high loadings on both sea level pressure and cloud cover and explains approximately $17 \%$ of the variance. Principal components 3 and 4 have their highest loadings on the $u$ - and $v$-component wind vectors, explaining $12 \%$ and $10 \%$ of the variance, respectively. The fifth principal component explains $5 \%$ of the variance and has moderate loadings on a number of different variables. Similar distributions are noted in the PCA of the winter and autumn seasons. Clustering the seasonal PCA loadings yields the synoptic weather types across the September-May snow season, and a daily synoptic calendar from 1960 to 2009 is generated. The daily synoptic calendar is then examined in conjunction with the identified daily ablation events to determine the synoptic weather types responsible for ablating snow within the Great Lakes basin.

While multiple synoptic weather types result in at least one basinwide snow-ablation event in excess of $2.54 \mathrm{~cm}$ from 1960 to 2009, only synoptic weather types that lead to at least one ablation event in every 4 years are analyzed. Ten synoptic weather types meet this criterion, producing $66 \%$ of the 349 total ablation events, and are examined in greater detail (Fig. 1; Table 1). Table 1 presents the composited meteorological conditions in Flint for each of these 10 synoptic weather types at four daily observation periods, along with general statistics.

Composite sea level pressure fields for each of the 10 synoptic weather types indicate the dominant pattern for ablation in the Great Lakes basin $(59 \%)$ is that of low pressure to the west and high pressure to the east (S1-S5 in Fig. 1, where S stands for the southerly-flow component; Table 1). This general pressure pattern is depicted in five of the synoptic weather types (S1-S5 in Fig. 1), resulting in south to south-southwest flow into the basin and advection of warm and potentially moist air north from the Gulf of Mexico. This advection would provide sufficient sensible and latent heat fluxes into the snowpack necessary for melt. Despite having similar synoptic-scale atmospheric patterns, the meteorological conditions for the individual synoptic weather types with this southerly-flow pattern do vary, in part because of their timing within the seasonal cycle (Table 1).

Two other dominant sea level pressure patterns are present among the most common ablation-causing synoptic weather types: rain-on-snow and overhead-high patterns. Weather types R1-R3 (where R stands for rain 
TABLE 1. Meteorological characteristics for the 10 most common synoptic weather types leading to ablation at Flint at 0900, 1500, 2100, and 0300 UTC and a statistical summary of the events.

\begin{tabular}{|c|c|c|c|c|c|c|c|c|c|c|c|}
\hline \multirow{2}{*}{$\begin{array}{l}\text { Time } \\
\text { (UTC) }\end{array}$} & \multirow[b]{2}{*}{ Variable } & \multicolumn{5}{|c|}{ Southerly flow } & \multicolumn{3}{|c|}{ Rain on snow } & \multicolumn{2}{|c|}{ High } \\
\hline & & S1 & S2 & S3 & S4 & S5 & $\mathrm{R} 1$ & $\mathrm{R} 2$ & R3 & $\mathrm{H} 1$ & $\mathrm{H} 2$ \\
\hline 0900 & Temperature $\left({ }^{\circ} \mathrm{C}\right)$ & 0.1 & 0.8 & 0.8 & 2.0 & -5.2 & 7.1 & 1.3 & 7.0 & -4.5 & -0.3 \\
\hline 0900 & Dewpoint $\left({ }^{\circ} \mathrm{C}\right)$ & -3.3 & -4.6 & -2.3 & -2.0 & -8.1 & 4.2 & -2.2 & 2.3 & -8.0 & -2.5 \\
\hline 0900 & Sea level pressure $(\mathrm{hPa})$ & 1020 & 1023 & 1023 & 1018 & 1020 & 1015 & 1021 & 1009 & 1028 & 1019 \\
\hline 0900 & Wind speed $\left(\mathrm{m} \mathrm{s}^{-1}\right)$ & 4.3 & 3.8 & 1.9 & 2.6 & 2.5 & 4.5 & 3.4 & 5.4 & 1.1 & 1.9 \\
\hline 0900 & Wind direction $\left({ }^{\circ}\right)$ & 197 & 182 & 176 & 207 & 134 & 197 & 136 & 190 & 322 & 16 \\
\hline 0900 & Cloud cover (tenths) & 6.8 & 2.9 & 6.5 & 0.9 & 4.1 & 8.8 & 7.1 & 6.2 & 0.7 & 7.9 \\
\hline 1500 & Temperature & 2.4 & 7.8 & 5.1 & 9.1 & 0.2 & 8.4 & 5.8 & 11.4 & 2.2 & 0.9 \\
\hline 1500 & Dewpoint & -1.7 & -1.9 & -0.8 & 0.1 & -3.6 & 5.8 & 0.2 & 4.4 & -6.7 & -1.8 \\
\hline 1500 & Sea level pressure & 1019 & 1021 & 1024 & 1018 & 1017 & 1015 & 1020 & 1007 & 1030 & 1022 \\
\hline 1500 & Wind speed & 5.2 & 6.1 & 3.2 & 4.3 & 5.0 & 5.3 & 5.3 & 7.5 & 0.2 & 2.9 \\
\hline 1500 & Wind direction & 198 & 197 & 182 & 214 & 152 & 198 & 154 & 216 & 14 & 26 \\
\hline 1500 & Cloud cover & 7.2 & 5.2 & 9.6 & 1.0 & 8.2 & 9.6 & 9.0 & 9.2 & 0.5 & 5.4 \\
\hline 2100 & Temperature & 6.6 & 14.0 & 9.6 & 15.2 & 5.4 & 11.4 & 11.5 & 14.0 & 7.5 & 5.6 \\
\hline 2100 & Dewpoint & 0.3 & 1.2 & -0.4 & 0.9 & -0.5 & 7.6 & 3.2 & 4.7 & -7.1 & -2.6 \\
\hline 2100 & Sea level pressure & 1016 & 1017 & 1021 & 1015 & 1012 & 1013 & 1015 & 1004 & 1028 & 1022 \\
\hline 2100 & Wind speed & 5.2 & 6.5 & 2.6 & 4.6 & 5.6 & 5.1 & 5.5 & 8.3 & 0.5 & 2.8 \\
\hline 2100 & Wind direction & 201 & 200 & 179 & 211 & 167 & 202 & 154 & 230 & 211 & 21 \\
\hline 2100 & Cloud cover & 7.7 & 8.1 & 8.9 & 2.2 & 9.2 & 8.9 & 8.3 & 8.7 & 0.7 & 5.2 \\
\hline 0300 & Temperature & 4.6 & 9.4 & 5.3 & 8.5 & 4.7 & 9.3 & 7.7 & 8.2 & 0.6 & 0.2 \\
\hline 0300 & Dewpoint & 0.6 & 2.5 & -0.2 & 1.7 & 1.6 & 6.9 & 3.2 & 3.1 & -6.3 & -2.5 \\
\hline 0300 & Sea level pressure & 1016 & 1016 & 1021 & 1014 & 1007 & 1014 & 1012 & 1008 & 1028 & 1023 \\
\hline 0300 & Wind speed & 4.7 & 4.7 & 2.8 & 3.4 & 6.9 & 4.3 & 5.1 & 4.6 & 1.8 & 2.5 \\
\hline 0300 & Wind direction & 198 & 182 & 149 & 182 & 170 & 206 & 149 & 245 & 142 & 75 \\
\hline 0300 & Cloud cover & 7.2 & 6.3 & 8.5 & 1.6 & 9.2 & 8.8 & 8.6 & 5.2 & 1.6 & 3.3 \\
\hline Total N & of ablation events & 47 & 28 & 25 & 26 & 10 & 28 & 19 & 15 & 16 & 15 \\
\hline Mean a & ation magnitude $(\mathrm{cm})$ & 4.3 & 3.7 & 3.4 & 3.4 & 3.5 & 4.5 & 3.6 & 3.6 & 4.1 & 3.7 \\
\hline Std dev & f mean $(\mathrm{cm})$ & 1.8 & 1.0 & 1.0 & 0.7 & 0.9 & 1.1 & 1.1 & 1.2 & 1.8 & 1.1 \\
\hline Max ab & tion magnitude $(\mathrm{cm})$ & 12.4 & 7.1 & 5.8 & 5.2 & 5.3 & 8.2 & 7.2 & 6.9 & 10.5 & 6.3 \\
\hline Total sr & w ablated $(\mathrm{cm})$ & 202 & 104 & 85 & 88 & 35 & 126 & 68 & 54 & 66 & 56 \\
\hline
\end{tabular}

on snow) are classified as rain-on-snow synoptic types resulting from a cyclonic system tracking over portions of the basin that results in advection of warm and moist air and liquid precipitation. For instance, type R1 produces approximate precipitation rates between $3-6 \mathrm{~mm}$ day $^{-1}$ per associated ablation event averaged across the basin. In addition to the warm air and dewpoint temperatures that result in relatively high sensible and latent heat fluxes into the snowpack, the rain-on-snow precipitation should contribute to snowmelt (Leathers et al. 1998; Levia and Leathers 2011). Rain-on-snow patterns are associated with approximately $27 \%$ of ablation events.

For types $\mathrm{H} 1$ and $\mathrm{H} 2$ (where $\mathrm{H}$ stands for high pressure overhead), there is a high pressure center directly over the Great Lakes basin, resulting in afternoon air temperatures above $5^{\circ} \mathrm{C}$, average dewpoint temperatures below $-3^{\circ} \mathrm{C}$, and light and variable winds in Flint (Table 1; $\mathrm{H} 1$ and $\mathrm{H} 2$ ). For type H1, there is almost no cloud cover in Flint and, from these average conditions, the bulk of the energy needed for ablation likely results from relatively warm air and high levels of incoming solar radiation reaching the snowpack (not shown). The high-pressure-overhead patterns are associated with approximately $14 \%$ of ablation events. Although not examined in detail, the synoptic types that cause the remaining $34 \%$ of ablation can still generally be grouped into one of these three main categories.

\section{b. Ablation case studies}

The magnitude of ablation during a particular synoptic weather type is determined by the availability of snow to ablate and the meteorological conditions and surface energy fluxes associated with a synoptic weather type. To examine the diversity of meteorological conditions associated with differing types, three case studies are examined for the most prominent patterns leading to ablation in the Great Lakes basin: southerly-flow, rain-on-snow, and overhead-high patterns. Surface pressure, temperature, dewpoint temperature, wind speed, cloud cover, and surface energy flux maps are generated from the North American Regional Reanalysis (NARR; Mesinger et al. 2006) data to depict the interactions among snow ablation, snow surface energy fluxes, and synoptic-scale circulation over the Great Lakes basin. The specific case 

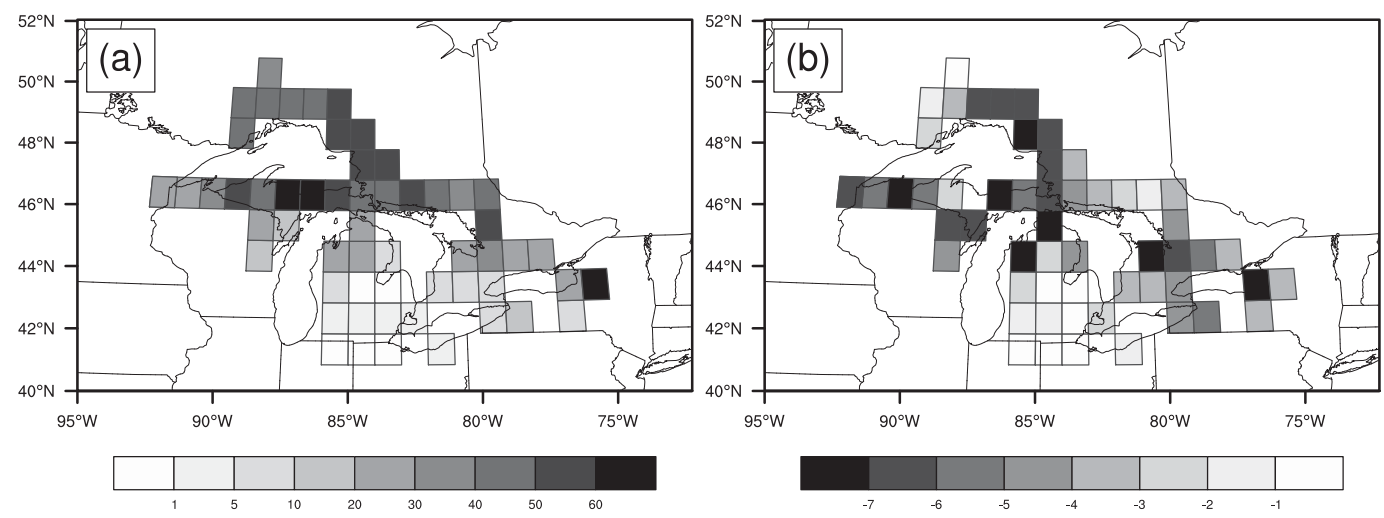

FIG. 2. Case study 1 for the Great Lakes basin: (a) snow depth preceding the event, and (b) spatial distribution of ablation. Darker shades $(\mathrm{cm})$ represent deeper depths and greater ablation.

studies are selected on the basis of the individual events resembling their respective composites for the particular synoptic type in terms of ablation magnitude and sea level pressure pattern. Meteorological characteristics and surface energy fluxes are daily averages.

\section{1) TYPE S1: SOUTHERLY-FLOW PATTERN, 10 FEBRUARY 2009}

The ablation event on 10 February 2009 provides an example of ablation associated with southerly-flow pattern $\mathrm{S} 1$. The event is characterized by extensive snow cover across the entire basin, with a basinwide average ablation of $5.34 \mathrm{~cm}$ over the course of the day (Figs. 2a, b). The day's sea level pressure depicts a low pressure center over North Dakota and broad high pressure along the Atlantic Coast that results in southerly flow into the basin from the Gulf of Mexico (Fig. 3a). The pressure pattern greatly influences the prevailing surface meteorological conditions across the basin. Surface flow advects surface air and dewpoint temperatures of greater than $0^{\circ} \mathrm{C}$ into a majority of the basin (Figs. 3b,c), where wind speeds range from $3 \mathrm{~m} \mathrm{~s}^{-1}$ east of Lake Erie to over $10 \mathrm{~m} \mathrm{~s}^{-1}$ west and north of Lakes Superior and Michigan (Fig. 3d). Cloud cover is less than $40 \%$ across the central and western portions of the basin and is approximately $70 \%$ over the eastern lakes (Fig. 3e).

The combination of relatively high wind speeds with air and dewpoint temperatures in excess of $0^{\circ} \mathrm{C}$ yields moderate-to-high levels of turbulent exchange between the atmosphere and snowpack. Between 35 and $70 \mathrm{~W} \mathrm{~m}^{-2}$ of sensible heat and $23-85 \mathrm{~W} \mathrm{~m}^{-2}$ of latent heat are transferred into the snowpack in the western and central regions of the basin (Figs. 4a,b). Net longwave radiation is away from the surface for nearly the entire basin and does not contribute to snow ablation (Fig. 4d); however, relatively high amounts of energy are transferred into the snowpack from shortwave radiation. Net shortwave radiation exceeds $60 \mathrm{~W} \mathrm{~m}^{-2}$ into the snowpack across much of the basin, with peak levels greater than $100 \mathrm{~W} \mathrm{~m}^{-2}$ corresponding to regions with lower cloud cover and where the snowpack is completely ablated over the event (Fig. 4c).

\section{2) TYPE R1: RAIN-ON-SNOW PATTERN, 13 FEBRUARY 1984}

A representative example of synoptic weather type R1 occurred on 13 February 1984, for which the rain-onsnow event ablated an average of $4.58 \mathrm{~cm}$ of snow across the basin, with the highest magnitudes of ablation occurring in southern Ontario, Canada (Figs. 5a,b). The $1000-\mathrm{hPa}$ low pressure system northwest of the basin and the strong high pressure center over the northern Atlantic Ocean contribute to south-southeasterly flow (Fig. 6a). This flow results in the advection of air and dewpoint temperatures exceeding $6^{\circ} \mathrm{C}$ into the central portion of the basin (Figs. 6b,c) with temperatures reaching $10^{\circ}-12^{\circ} \mathrm{C}$ as far north as $46^{\circ} \mathrm{N}$ at 0000 UTC (not shown). Daily-averaged wind speeds are a moderate $6 \mathrm{~m} \mathrm{~s}^{-1}$ over much of the basin (Fig. 6d). Cloud cover over $50 \%$ is prominent across much of the basin, with the exception of the easternmost reaches of the basin, which exhibit less than $30 \%$ cloud cover (Fig. 6e). In addition, there is substantial liquid precipitation during the event, with regions in southern Ontario receiving in excess of $3.0 \mathrm{~cm}$ over the calendar day (Fig. 6f).

The dominant components of energy fluxes into the snowpack during the event are sensible and latent heat, with maximum energy transfers into the snow surface of $67-94 \mathrm{~W} \mathrm{~m}^{-2}$ to the east of Lakes Huron, Erie, and Ontario corresponding to the regions of peak snow ablation (Figs. 7a,b). Relatively high air and dewpoint temperatures coupled with moderate-to-high wind speeds in these regions provide the bulk of this energy exchange. The liquid precipitation associated with the 

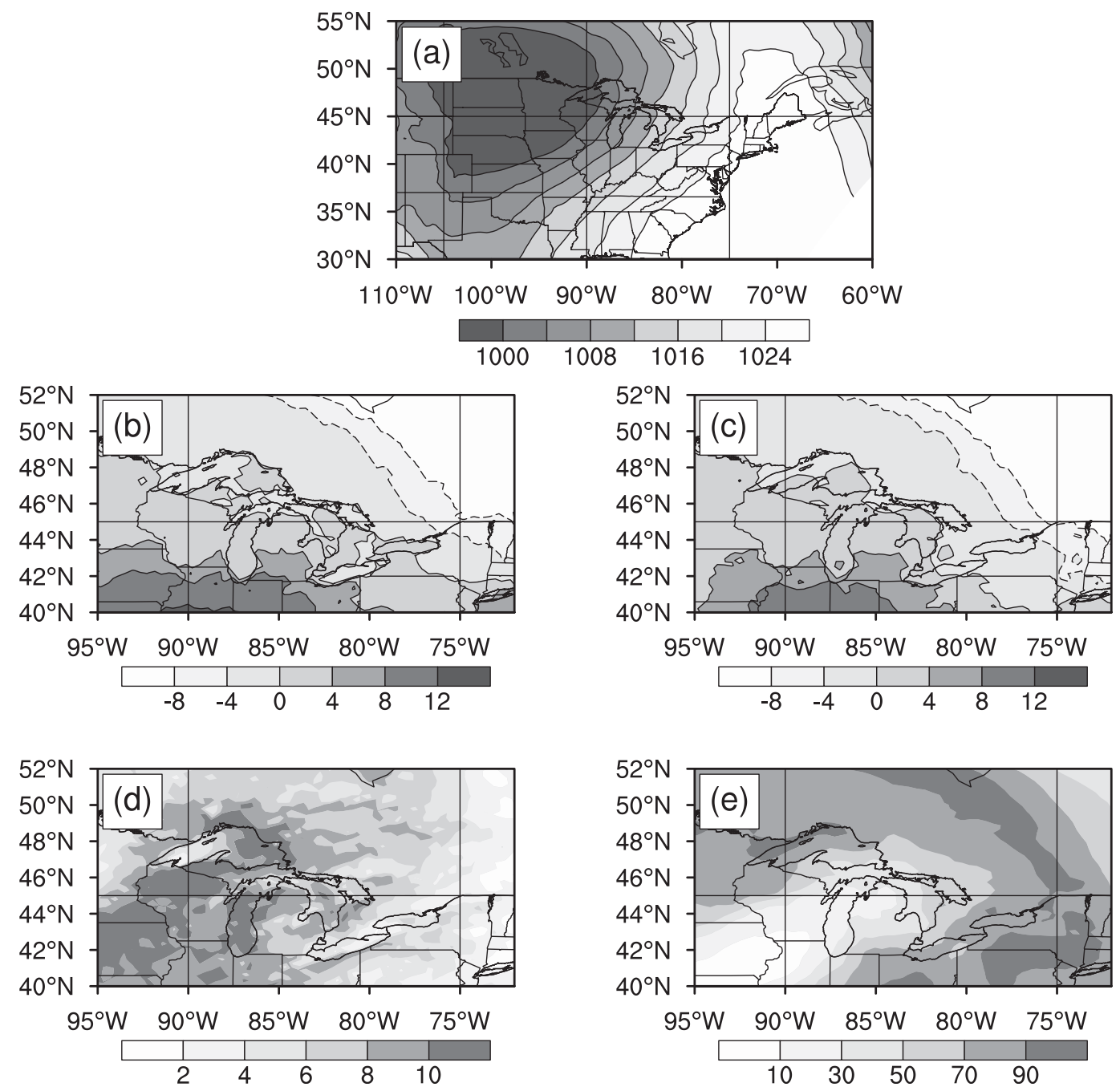

FIG. 3. (a) Sea level pressure (hPa), (b) surface air temperature $\left({ }^{\circ} \mathrm{C}\right)$, (c) surface dewpoint temperature $\left({ }^{\circ} \mathrm{C}\right)$, (d) surface wind speed $\left(\mathrm{m} \mathrm{s}^{-1}\right)$, and (e) cloud cover (\%) from the NARR during case study 1 on 10 Feb 2009.

event should additionally contribute to sensible heat transfer into the snowpack upon contact cooling, and/or in latent heat transfer if the precipitation eventually freezes onto the snowpack. Similar to the first case study [section $3 b(1)]$, net longwave radiation is negative and away from the surface (Fig. 7d). In the most southeastern and southwestern extremes of the basin there is a net gain of shortwave radiation at the snow surface in excess of $50 \mathrm{~W} \mathrm{~m}^{-2}$; however, in regions that experienced the most ablation, net shortwave radiation is only minimal at approximately $25 \mathrm{~W} \mathrm{~m}^{-2}$ (Fig. 7c).

\section{3) TyPe H1: OVERHEAD-HIGH PATTERN, 18 MARCH 2001}

An example of synoptic weather type $\mathrm{H} 1$ occurs on 18 March 2001, for which there is a latitudinal gradient of snow depth in the basin, where the northerly regions have depths over $70 \mathrm{~cm}$ (Fig. 8a). Spatially, the ablation magnitude is relatively widespread, resulting in a basinwide average of $4.55 \mathrm{~cm}$ (Fig. 8a). The synoptic-scale circulation is characterized by a $1028-\mathrm{hPa}$ high pressure center directly over the Midwest and Great Lakes regions (Fig. 9a). Surface air and dewpoint temperatures are below freezing over the entire day (Figs. 9b,c) and wind speeds are generally weak over much of the region, with the exception of the easternmost reaches of the basin in New York State, where speeds in excess of $6 \mathrm{~m} \mathrm{~s}^{-1}$ are recorded (Fig. 9d). With high pressure overhead, cloud cover in the basin is minimal $(<20 \%)$, allowing for high levels of incoming shortwave radiation to reach the surface (Fig. 9e). With the event occurring in mid-March, the solar angle is relatively high in comparison with the winter season, increasing the incoming shortwave radiation at the surface. 

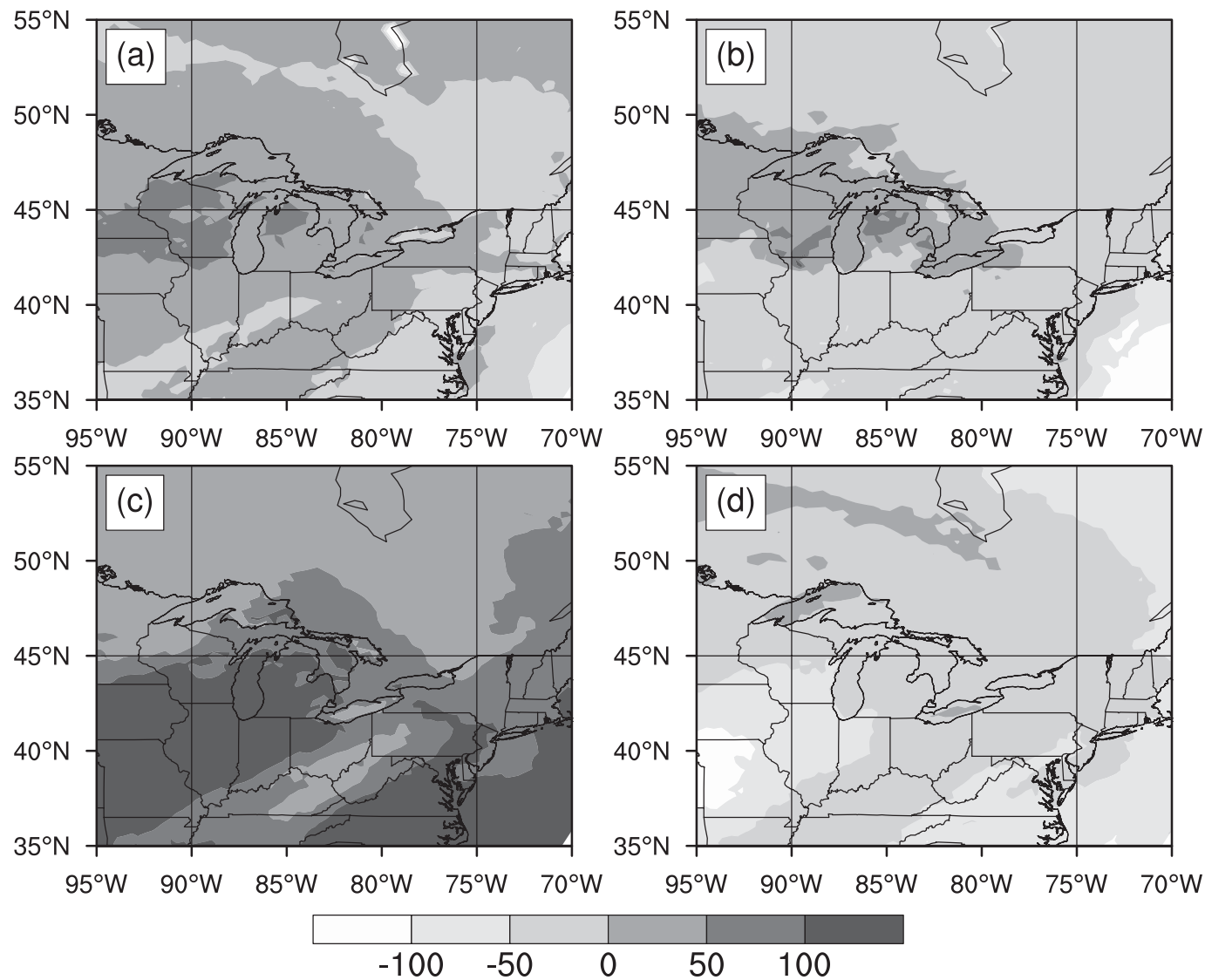

FIG. 4. Net snow surface energy fluxes during case study 1 on 10 Feb 2009, with positive values (dark shades) representing energy transfer into the surface: (a) sensible heat flux, (b) latent heat flux, (c) net shortwave radiation, and (d) net longwave radiation.

In examination of the surface energy fluxes (Fig. 10), almost all of the energy being transferred into the snow surface is from net shortwave radiation, with rates exceeding $100 \mathrm{Wm}^{-2}$ over nearly the entire basin (Fig. 10c). Net longwave radiation (Fig. 10d) and the latent heat fluxes (Fig. 10b) are negative and away from the snow surface across the basin, not contributing to snow ablation. There is minimal sensible heat exchange $\left(<20 \mathrm{~W} \mathrm{~m}^{-2}\right)$ from the atmosphere into the snow surface along the shores of Lake Superior, with temperatures below freezing and wind speeds below $4 \mathrm{~m} \mathrm{~s}^{-1}$ (Fig. 10a). Across the remainder of the basin
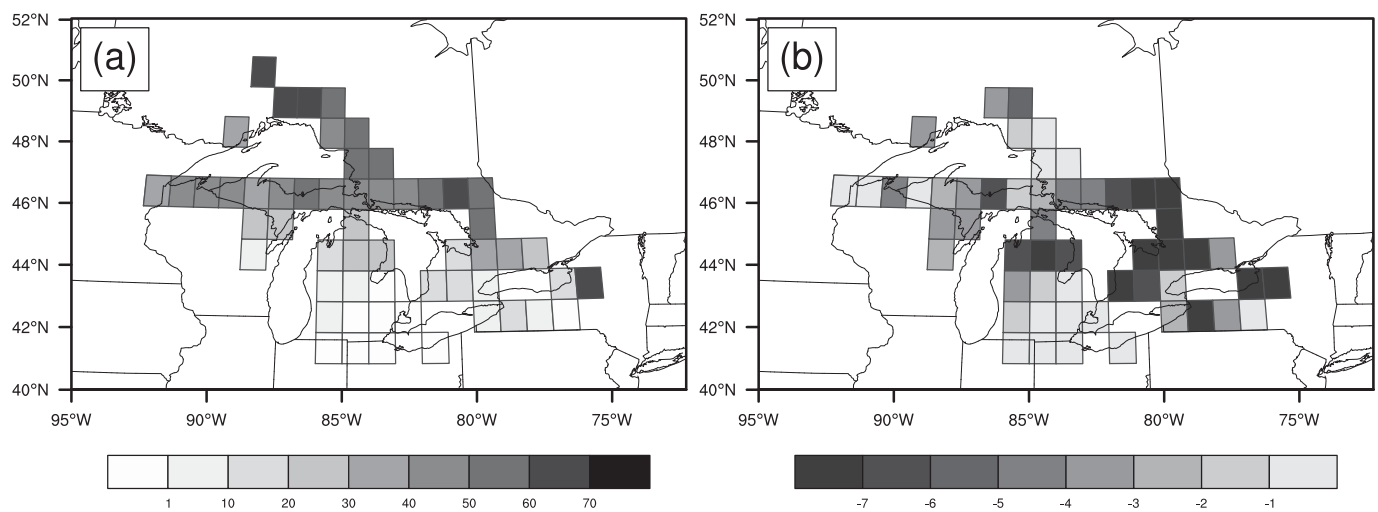

FIG. 5. As in Fig. 2, but for case study 2. 

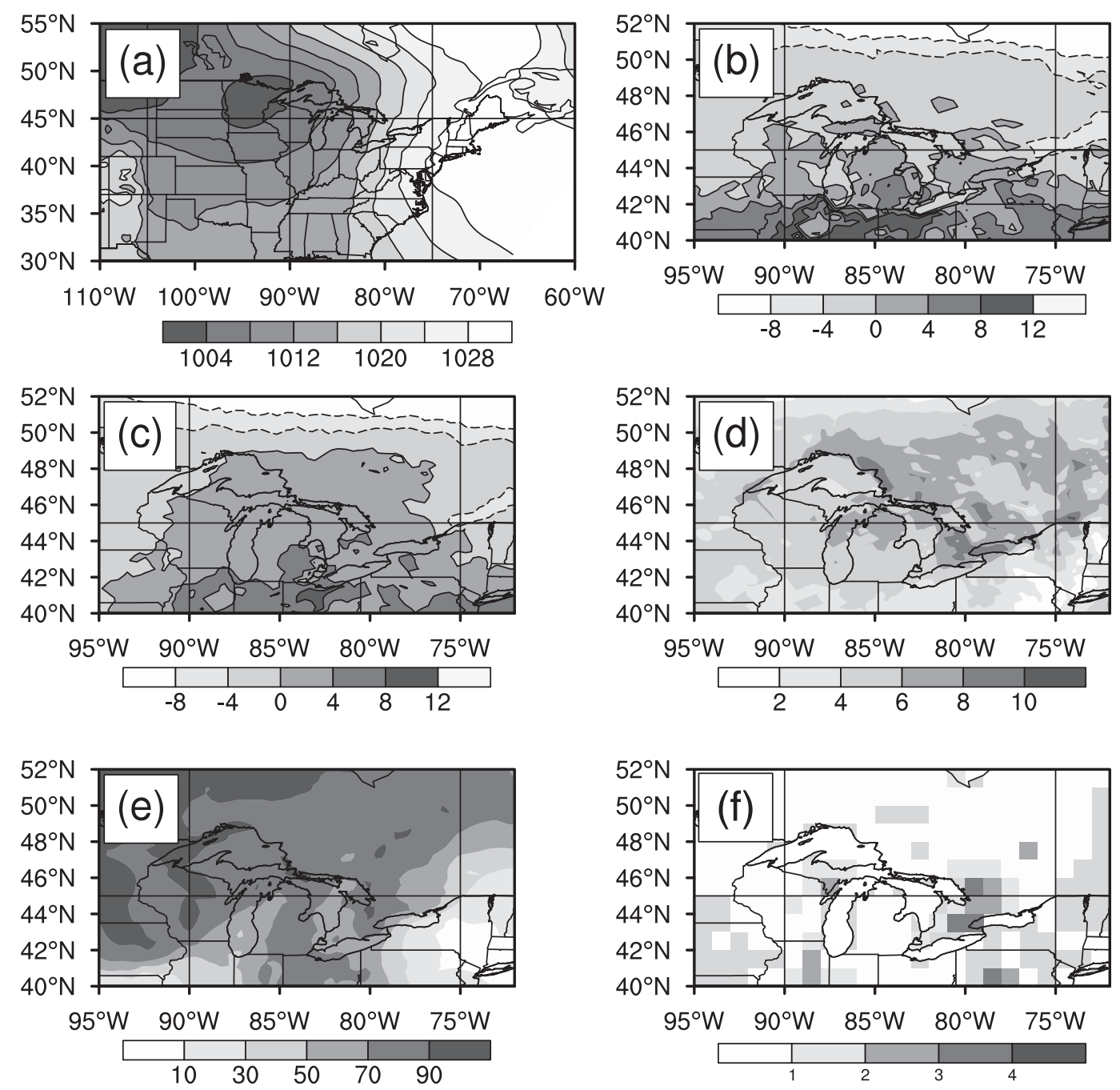

FIG. 6. As in Fig. 3, but for case study 2 on 13 Feb 1984 and adding (f) daily liquid precipitation total (cm).

the sensible heat flux is negative and away from the snow surface.

\section{c. Interannual variability of synoptic types}

While snow cover is necessary for an ablation event to occur, examining the frequency of the previously identified synoptic types indicates how atmospheric circulation responsible for ablation varies and may be changing over time. Examining the interannual frequency of synoptic types that lead to ablation by the general categories presented previously (southerly flow, rain on snow, and high pressure overhead), substantial variability is present from 1960 to 2009 (Fig. 11). The southerly-flow synoptic types are most prevalent, occurring approximately 26.3 days per year, followed by high pressure overhead and rain-on-snow types occurring 12.0 and 11.0 days per year respectively. Trends in the interannual frequency of each synoptic type category are examined using simple linear regression. The frequency of rain-on-snow synoptic types is statistically significantly declining by 0.10 days per year, or 5.1 days over the 50 -yr period (level $p<0.01$ ). Such a decline represents an approximate $37 \%$ decrease. Conversely, the frequency of high-pressure-overhead types is significantly increasing by 0.07 days per year, or 3.5 days over 1960-2009 $(p<0.05)$.

\section{Discussion and conclusions}

In the Great Lakes basin of North America, three general synoptic weather types can explain the majority of basinwide snowmelt events of greater than $2.54 \mathrm{~cm}$ during the 1960-2009 period: southerly-flow, rain-onsnow, and high-pressure-overhead patterns. The most 

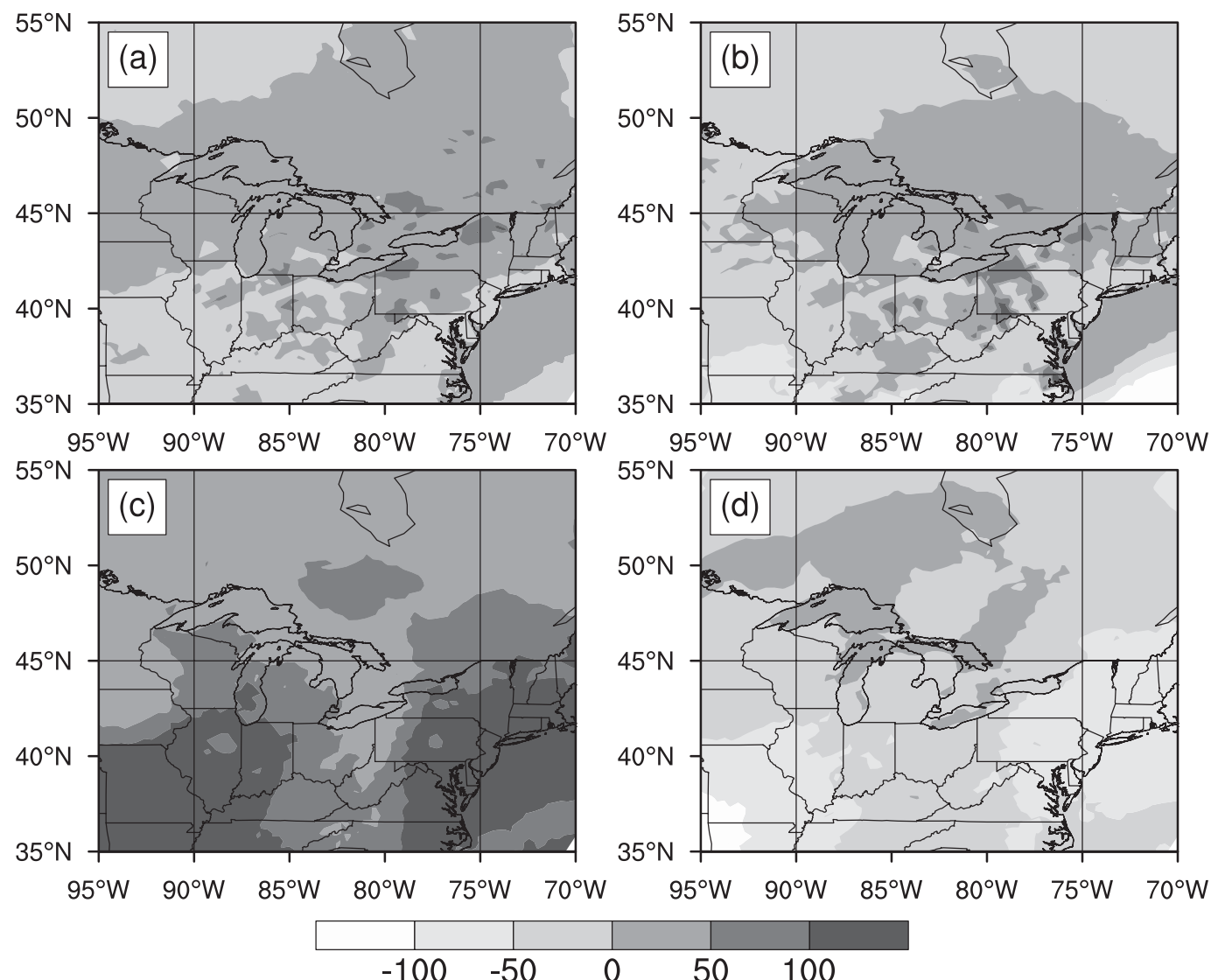

FIG. 7. As in Fig. 4, but for case study 2 on 13 Feb 1984.

common type is that of a midlatitude cyclone to the west and an anticyclone to the east and south of the basin, resulting in advection of unseasonably warm and potentially moist air from the Gulf of Mexico, with sensible, latent, and net shortwave radiation all contributing to the transfer of energy into the snowpack necessary for ablation. In a similar way, a second synoptic type leading to ablation also has a midlatitude cyclone in the vicinity of the basin, leading to advection of warm and moist air; however, for these types liquid precipitation aids in snowmelt and the sensible and latent heat fluxes dominate the local energy transfer. The third type is that of high pressure overhead, resulting in low cloud cover basinwide and
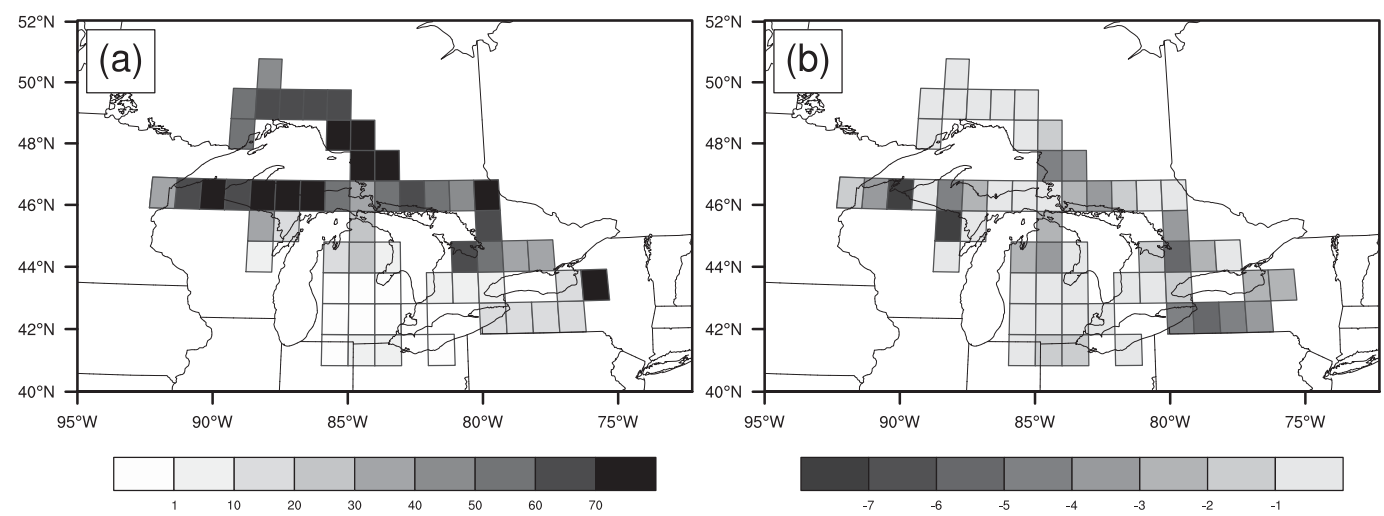

FIG. 8. As in Fig. 2, but for case study 3. 

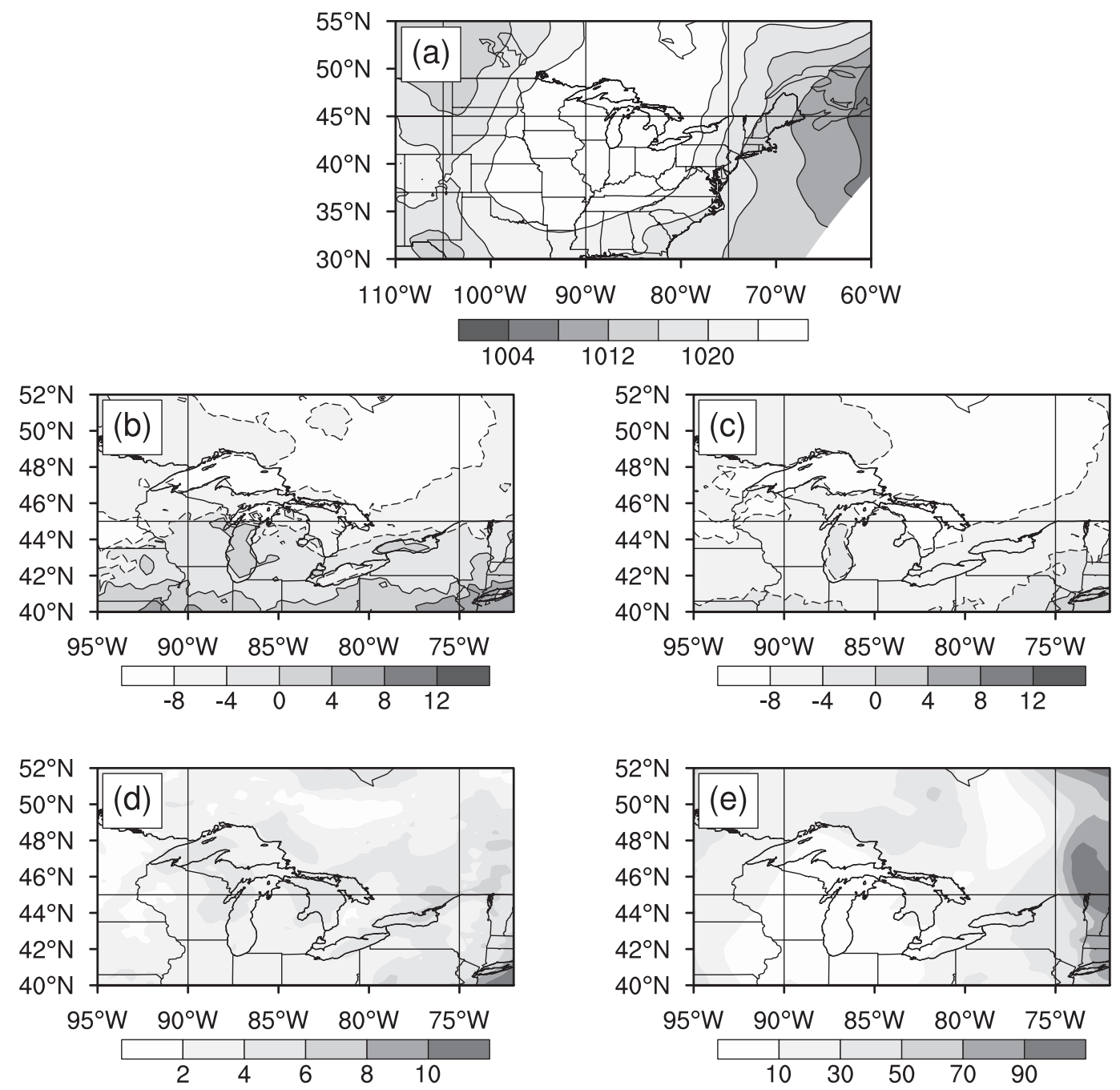

FIG. 9. As in Fig. 3, but case study 3 on 18 Mar 2001.

thus increasing the potential for enhanced levels of incoming solar radiation reaching the snowpack and inducing melt; net shortwave radiation represents between $90 \%$ and $100 \%$ of the total energy transfer into the basin.

To ascertain whether long-term changes in the frequency of these patterns are occurring, simple linear regression is performed. The interannual frequency of high-pressure-overhead synoptic types significantly increased by over $34 \%$ from 1960 to 2009 . These types result in approximately $3.8 \mathrm{~cm}$ of snow ablation per event and contribute substantially to the total amount of snow ablated across the basin. The frequency of rainon-snow synoptic types is significantly declining over the 50 -yr period, with a linearly extrapolated decrease from 13.6 to 8.5 days per year from 1960 to 2009. Of the general synoptic categories, rain-on-snow synoptic types on average ablate the highest amount of basinwide average snow cover, at approximately $4.0 \mathrm{~cm}$ per event. Rain-on-snow conditions are often associated with the largest snowmelt-induced flooding events in midlatitude regions because of the addition of liquid precipitation to the snow-generated runoff (e.g., Leathers et al. 1998). Detecting the significant decrease in the frequency of these synoptic conditions is important: fewer instances of rain-on-snow synoptic conditions suggest a decrease to the hydrologic impact of these types and their probability of producing potentially hazardous flooding conditions.

The synoptic weather conditions leading to ablation in the Great Lakes basin are broadly similar to conditions shown to cause snow ablation in other midlatitude regions. In the North American Great Plains, the three synoptic patterns associated with snowmelt involve a 

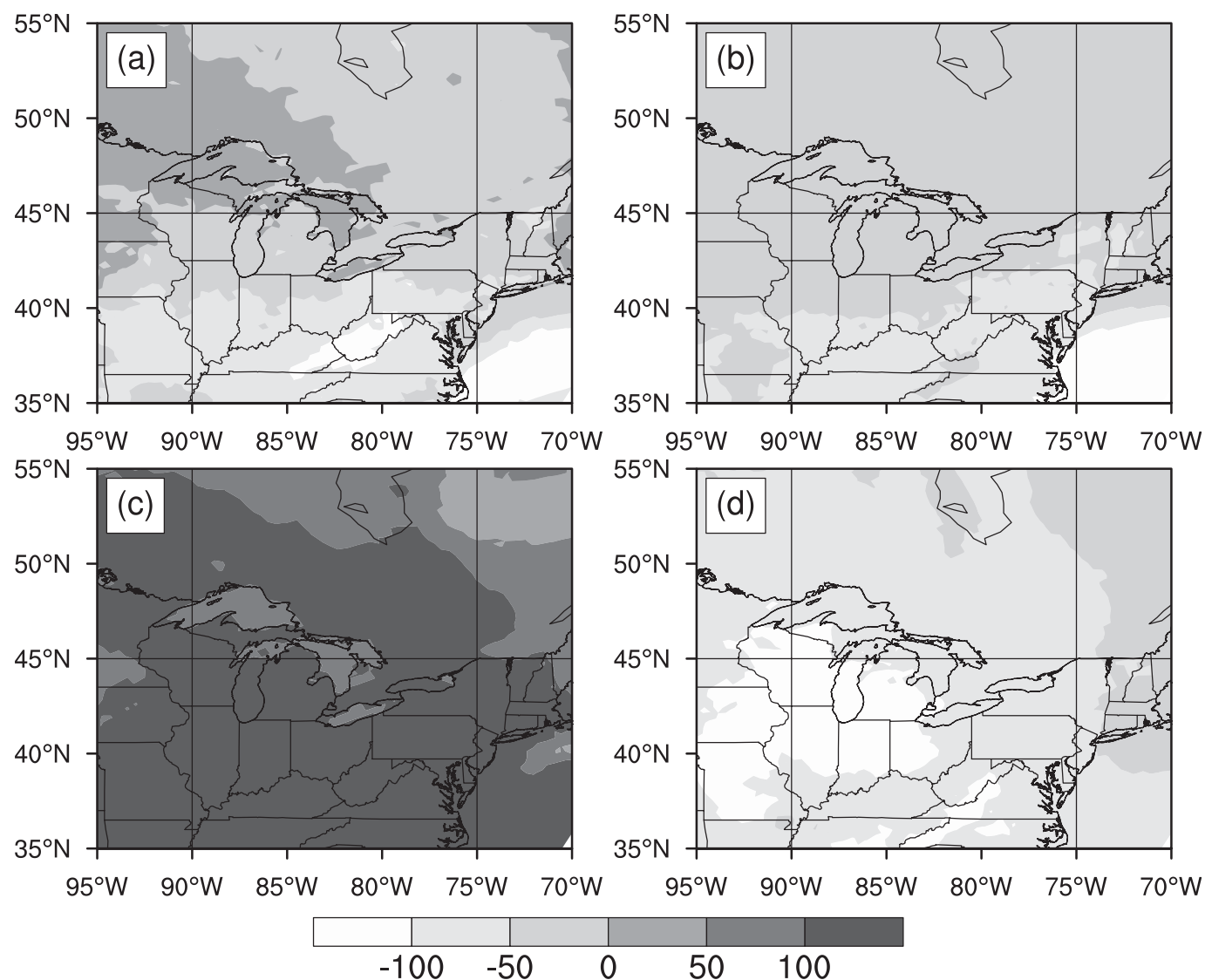

FIG. 10. As in Fig. 4, but for case study 3 on 18 Mar 2001.

midlatitude cyclone tracking through the region and advecting warm air from the south (Grundstein and Leathers 1998, 1999). Ablation in the west Siberian plain is associated with four different circulation types that include westerly-flow, southwesterly-flow, and southerlyflow types (Bednorz and Wibig 2015). Melt events in the Polish-German lowlands are favored when anomalously strong low pressure systems are present in the northern Atlantic Ocean and high pressure is over the Mediterranean Sea (Bednorz 2009). Such a pattern brings warm maritime air and often higher-than-usual precipitation into the region, inducing snowmelt. In the central Appalachian Mountains, a majority of ablation events occur during "moist" air masses with cloudy, windy conditions and high dewpoint temperatures; however, "dry" air masses with clear skies also cause events (Leathers et al. 2004).

This paper focused on the atmospheric forcings of snow-cover ablation in the Great Lakes basin, highlighting the diversity of atmospheric and meteorological conditions that lead to snow-ablation events. The variability of snow-cover ablation, however, is dependent on both the overlying atmospheric conditions that induce ablation and the availability of sufficient snow depth to be ablated. While snow cover exists across the entire basin seasonally, there is substantial temporal and spatial variability in the depth of snow. Preliminary findings suggest that the average seasonal basinwide snow depth is significantly declining by approximately $25 \%$ over $1960-2009$, whereas particular subregions have differing trends, potentially because of changing snowfall totals. Such changes in average snow depth could affect the frequency or magnitude of ablation events, given the availability of snow to ablate. A thorough investigation into the role of spatial and temporal snow-depth variability on snow ablation is currently under way. In addition, whereas this study inspected energy fluxes associated with the three ablation case studies, a more exhaustive examination into these snow-surface fluxes and how they are changing over time for each of the primary ablation-causing synoptic weather types will be conducted in future studies. Continued research into the interactions between snow ablation and atmospheric circulation is 

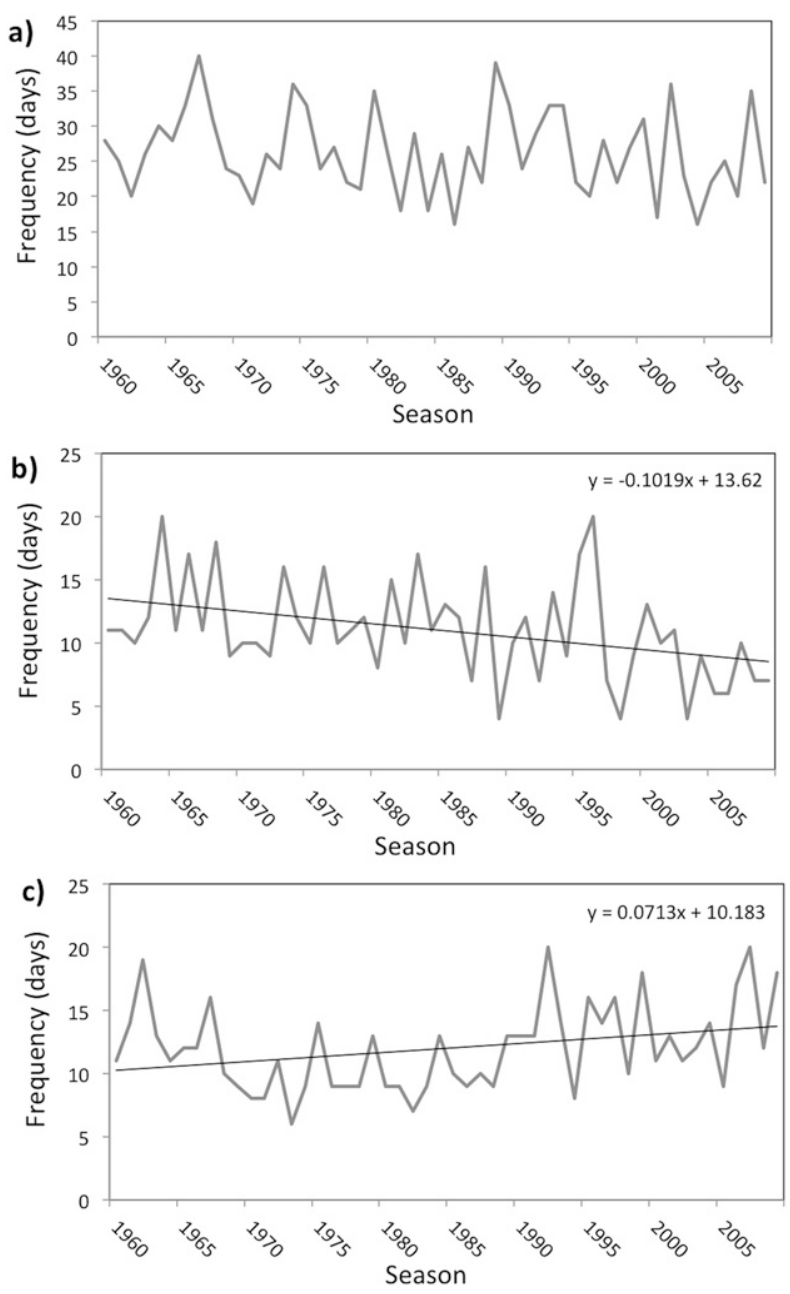

FIG. 11. Interannual frequency from 1960 to 2009 of the general ablation-inducing synoptic categories: (a) southerly flow, (b) rain on snow, and (c) high pressure overhead. The frequencies of the rain-on-snow and high-overhead synoptic categories are respectively significantly decreasing and increasing, and a linear regression line is included in (b) and (c) to show those trends.

useful for operational hydrological forecasting and regional water management.

Acknowledgments. Partial funding for this research was provided by National Oceanic and Atmospheric Administration Climate Program Office Grant NA14OAR4310207 and the Department of Geography at the University of Delaware.

\section{REFERENCES}

Anderson, E. A., 1976: A point energy and mass balance model of a snow cover. NOAA Tech. Rep. NWS 19, 150 pp., http:// amazon.nws.noaa.gov/articles/HRL_Pubs_PDF_May12_ 2009/HRL_PUBS_51-100/81_A_POINT_ENERGY_AND_ MASS.pdf.
Barnett, T. P., J. C. Adam, and D. P. Lettenmaier, 2005: Potential impacts of a warming climate on water availability in snowdominated regions. Nature, 438, 303-309, https://doi.org/ 10.1038/nature04141.

Bednorz, E., 2009: Synoptic conditions for rapid snowmelt in the Polish-German lowlands. Theor. Appl. Climatol., 97, 279-286, https://doi.org/10.1007/s00704-008-0063-z.

_- and J. Wibig, 2015: Spatial distribution and synoptic conditions of snow accumulation and snow ablation in the west Siberian plain. Quest. Geogr., 34, 5-15, https://doi.org/10.1515/ quageo-2015-0029.

Changnon, S. A., 2008: Assessment of flood losses in the United States. J. Contemp. Water Res. Educ., 138, 38-44, https:// doi.org/10.1111/j.1936-704X.2008.00007.x.

Colbeck, S. C., 1983: Theory of metamorphism of dry snow. J. Geophys. Res., 88, 5475-5482, https://doi.org/10.1029/ JC088iC09p05475.

Déry, S. J., and M. K. Yau, 2002: Large-scale mass balance effects of blowing snow and surface sublimation. J. Geophys. Res., 107, 4679, https://doi.org/10.1029/2001JD001251.

Dyer, J. L., and T. L. Mote, 2006: Spatial variability and trends in observed snow depth over North America. Geophys. Res. Lett., 33, L16503, https://doi.org/10.1029/2006GL027258.

$\longrightarrow$, and —, 2007: Trends in snow ablation over North America. Int. J. Climatol., 27, 739-748, https://doi.org/ $10.1002 /$ joc. 1426 .

Ellis, A. W., and D. J. Leathers, 1996: A synoptic climatological approach to the analysis of lake-effect snowfall: Potential forecasting applications. Wea. Forecasting, 11 216-229, https://doi.org/10.1175/1520-0434(1996)011<0216: ASCATT $>2.0 . C O ; 2$.

Fracz, A., and P. Chow-Fraser, 2013: Impacts of declining water levels on the quantity of fish habitat in coastal wetlands of eastern Georgian Bay, Lake Huron. Hydrobiologia, 702, 151169, https://doi.org/10.1007/s10750-012-1318-3.

Grundstein, A. J., and D. J. Leathers, 1998: A case study of the synoptic patterns influencing midwinter snowmelt across the northern Great Plains. Hydrol. Processes, 12, 2293-2305, https://doi.org/10.1002/(SICI)1099-1085(199812)12:15<2293:: AID-HYP797>3.0.CO;2-9.

_, and — 1999: A spatial analysis of snow-surface energy exchanges over the northern Great Plains of the United States in relation to synoptic scale forcing mechanisms. Int. J. Climatol., 19, 489-511, https://doi.org/10.1002/(SICI)10970088(199904)19:5<489::AID-JOC373>3.0.CO;2-J.

Kalkstein, L. S., and P. Corrigan, 1986: A synoptic climatological approach for geographical analysis: Assessment of sulfur-dioxide concentrations. Ann. Assoc. Amer. Geogr., 76, 381-395, https://doi.org/10.1111/j.1467-8306.1986.tb00126.x.

, G. Tan, and J. Skindlov, 1987: An evaluation of three clustering procedures for use in synoptic climatological classification. J. Climate Appl. Meteor., 26, 717-730, https://doi.org/ 10.1175/1520-0450(1987)026<0717:AEOTCP >2.0.CO;2.

Kluver, D., T. Mote, D. J. Leathers, G. R. Henderson, W. Chan, and D. A. Robinson, 2016: Creation and validation of a comprehensive $1^{\circ}$ by $1^{\circ}$ daily gridded North American dataset for 1900-2009: Snowfall. J. Atmos. Oceanic Technol., 33, 857871, https://doi.org/10.1175/JTECH-D-15-0027.1.

Leathers, D. J., D. R. Kluck, and S. Kroczynski, 1998: The severe flooding event of 1996 across north-central Pennsylvania. Bull. Amer. Meteor. Soc., 79, 785-798, https:// doi.org/10.1175/1520-0477(1998)079<0785:TSFEOJ > 2.0.CO;2. 
D. Graybeal, T. L. Mote, A. Grundstein, and D. A. Robinson, 2004: The role of airmass types and surface energy fluxes in snow cover ablation in the central Appalachians. J. Appl. Meteor., 43, 1887-1899, https://doi.org/10.1175/ JAM2172.1.

Levia, D. F., and D. J. Leathers, 2011: Rain-induced snowmelt. Encyclopedia of Snow, Ice and Glaciers, V. P. Singh, P. Singh, and U. K. Haritashya, Eds., Encyclopedia of Earth Sciences Series, Springer-Verlag, 915-917, https://doi.org/10.1007/97890-481-2642-2.

Mesinger, F., and Coauthors, 2006: North American Regional Reanalysis. Bull. Amer. Meteor. Soc., 87, 343-360, https:// doi.org/10.1175/BAMS-87-3-343.

Quinn, F. H., 2002: Secular changes in Great Lakes water level seasonal cycles. J. Great Lakes Res., 28, 451-465, https:// doi.org/10.1016/S0380-1330(02)70597-2.
Robinson, D. A., 1988: Construction of a United States historical snow database. Proc. 45th Eastern Snow Conf., Lake Placid, NY, Eastern Snow Conference, 50-59.

Suriano, Z. J., and D. J. Leathers, 2017a: Spatio-temporal variability of Great Lakes basin snow cover ablation events. Hydrol. Processes, 31, 4229-4237, https://doi.org/10.1002/hyp.11364.

_ and _ 2017b: Synoptically classified lake-effect snowfall trends to the lee of Lakes Erie and Ontario. Climate Res., 74, 1-13, https://doi.org/10.3354/cr01480.

_ and - 2017c: Synoptic climatology of lake-effect snowfall conditions in the eastern Great Lakes region. Int. J. Climatol., 37, 4377-4389, https://doi.org/10.1002/joc.5093.

Wilks, D. S., 2011: Statistical Methods in the Atmospheric Sciences. 3rd ed. Elsevier, 676 pp.

Yarnal, B., 1993: Synoptic Climatology in Environmental Analysis: A Primer. Belhaven Press, 195 pp. 